\title{
The Construction, Mobilization and Limits of South Asianism in North America
}

\section{Anouck Carsignol}

\section{(2) OpenEdition}

\section{Journals}

\section{Electronic version}

URL: http://journals.openedition.org/samaj/3766

DOI: 10.4000/samaj.3766

ISSN: $1960-6060$

\section{Publisher}

Association pour la recherche sur l'Asie du Sud (ARAS)

\section{Electronic reference}

Anouck Carsignol, «The Construction, Mobilization and Limits of South Asianism in North America », South Asia Multidisciplinary Academic Journal [Online], 10 | 2014, Online since 25 December 2014 connection on 30 April 2019. URL : http://journals.openedition.org/samaj/3766 ; DOI : 10.4000/ samaj.3766

This text was automatically generated on 30 April 2019

\section{$(1 \otimes \Theta$}

This work is licensed under a Creative Commons Attribution-NonCommercial-NoDerivatives 4.0 International License. 


\title{
The Construction, Mobilization and Limits of South Asianism in North America
}

\author{
Anouck Carsignol
}

\section{Introduction}

1 In North America, the adjective 'South Asian"1 is widely used these days by the media, in academia and in politics to refer to people originating from Bangladesh, Bhutan, India, Maldives, Nepal, Pakistan, Sri Lanka, Afghanistan, ${ }^{2}$ and sometimes Burma and Tibet. More than a mere census category or point of geographic origin, this label has recently become an identity marker, claimed by certain members of the diaspora themselves. Beyond cultural or ethnic commonalities anchored in the Indian Subcontinent, the idea of 'South Asianism ${ }^{3}$ emerged as a form of political consciousness and activism, allegedly transcending national borders in order to promote pluralism, secularism and progressive politics.

2 The category 'South Asian' remains nevertheless highly contested, both externally and internally. In North America, this expression is often used indiscriminately, to refer to Asians in general or to Indians in particular. The term is not unanimously accepted by migrants either. For instance, partisans of religious nationalist movements reject the idea of a transnational, secular and regional identity. As for intellectuals, leftists, social workers, writers and artists originating from the subcontinent, even if most of them endorse this umbrella term, some of them nevertheless consider the category 'South Asian' a post-migration artefact, a neo-colonial invention, a political utopia or a romantic myth. Political and economic analyst S. Akbar Zaidi, originating from Pakistan, thus questions its validity: '[...] as a non-Indian citizen of South Asia, I often wonder whether the concept is meant to achieve anything beyond the legitimization of Indian hegemonycultural, geographic, economic' (Zaidi 2002). Others, on the contrary, such as musician 
and activist DJ Rekha, or queer ${ }^{4}$ rights activist Urvashi Vaid, use this label as a means of resistance to traditional or homogeneous identities, both within the group of migrants of South Asian descent, and in society at large.

3 When and where did the term 'South Asian' first appear? How did it evolve, historically and geographically, as well as conceptually? Who is categorized as South Asian today, and who claims to be so? Is mobilization in the name of a pan-South Asian identity merely the expression of ethnic and cultural affiliation, or is it instead focused on a tangible socioeconomic or political project? Is 'South Asianism' oriented toward the subcontinent, or is it centred on migrants in North America? Is this a label without content, or is it the symbol of a collective affirmation, the foundation for a neo-diaspora?

4 The purpose of this article is not so much to determine whether the term 'South Asian' is historically legitimate, politically correct, culturally authentic or sociologically relevant, but to understand its underlying identity and ideology, by examining the evolution of the concept and commenting on its limitations. More specifically, the objective is to analyze the apparent dichotomy between locality and identity, between the roots of a diasporic construction, traced back to the South Asian subcontinent, and its actual mobilization and focus, in North America. Based on a combination of ethnographic fieldwork and an analysis of digital networks, this paper sheds light on a dissenting, 'post-diasporic' movement, which epitomizes the idea of militant, cultural and political deterritorialization and relocalization (Deleuze \& Guattari 1972, Appadurai 1990).

\section{Construction and transformations of a South Asian category and identity in North America}

5 The process of naming and self-naming is at the core of identity politics, diversity management and power assertion. At the community level, self-naming can be seen as a way to affirm the group's identity, and thus to resist assimilation. At the society level, naming a population is part of the hegemonic group's strategy to create boundaries and reinforce its power over members of minorities, through the use of derogatory terms, racial categories or implicit hierarchies. Historically misnamed and marginalized by their host state, migrants originating from the Indian subcontinent reacted in various ways to official and popular categorizations, thus epitomizing the fact that subjectivation, that is, the constitution of individual and collective identities, can be both alienating and liberating (Butler 2007). This first part analyses the intricate history of the term 'South Asian', which results from a combination of exo-designation and self-representation processes, and takes its roots in North America, while remaining connected to the subcontinent.

\section{The Ghadar movement and the birth of a pan-South Asian solidarity}

6 A sense of common ancestry and destiny emerged among migrants originating from the subcontinent and settled in North America, long before the idea of South Asia was explicitly formulated. This nebulous umbrella identity owed its very existence to the racist undertones and the colonial context of the $19^{\text {th }}$ century when South Asia, then a loosely defined entity administered by a combination of colonial and local authorities, was commonly known as 'Indian Empire', 'British India' or 'Hindustan'. In the 1890s, the 
first migrants who used to define themselves as 'British Indians', or more specifically, as 'Punjabis', 'Sylhetis' or 'Bengalis' depending on their region of origin, were indiscriminately and depreciatively designated as 'Hindus', 'Brown' or 'Orientals' in North America. In reaction to an anti-Asian climate, which also targeted Japanese and Chinese migrants, and resulted in a ban on Asian migration (from 1913 to 1946 in the United States, and from 1908 to 1947 in Canada), radical associations such as the India Welfare League, the India League of America, the United Indian League, the Hindustan Students Association or the Hindu Workers Union of America sprang up in New York, San Francisco and Vancouver. Despite their internal differences in terms of caste, language, religion and socio-economic status, migrants originating from the subcontinent coalesced to lobby in favour of equality of treatment and freedom of movement. Facing rejection of their demands, they established a link between the predicament of India-under British domination-and the status of Indian migrants, who suffered from discrimination (Jüergensmeyer 1997). Funded in San Francisco in 1913, and particularly active in British Columbia, the revolutionary and secular Ghadar movement played a major role in the formation of a militant and secular pan-Indian solidarity overseas:

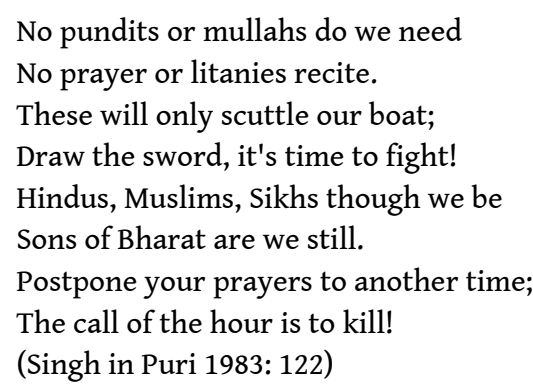

7 Among Ghadar's prominent figures were educated nationalist revolutionaries originating from different parts of India, such as Lala Har Dayal, Sohan Singh Bhakna, and Tarak Nath Das. The latter published the first South Asian publications in Canada (Free Hindustan) and established the Hindustani Association in Vancouver in 1907, before settling down in the United States where he relentlessly called 'Asian Youth' to resist the West. As for Rash Behari Bose, he initiated campaigns on behalf of Indian independence and Pan-Asianism from India and Japan, while Abdul Hafiz Mohamed Barakatullah advocated unity between Hindus and Muslims against British imperialism. With members dispatched around the world, the Ghadar became a transnational counter-movement, anchored in the diaspora and ideologically defined as 'almost exclusively nationalist, with a touch of utopian socialism [...], actively involved in international communism' (Jüergensmeyer 1979: 184). Vehemently secular, although steeped in Sikhism, the Ghadar was also a source of ethnic pride, inspiring the cohesion of British Indians in North America.

8 At the same time, the Satyagrahis' mobilization in Natal, South Africa, ${ }^{5}$ the Girmitiyas' revolts in Fiji, ${ }^{6}$ and the indentured workers' protests in the Caribbean islands ${ }^{7}$ served to build the base of a tradition of contestation against imperialism, racial discrimination and socio-economic injustice, a movement that carried on within the Indian diaspora at large until 1947. While using very different means of action, these various initiatives converged towards the same objectives: the liberation of India and the protection of migrants and workers abroad. As for the Indian intelligentsia and the political leaders in the subcontinent, they mobilized in favour of overseas Indians during colonial occupation, and petitioned in particular for the abolition of the indenture system, thus using a 
transnational cause to support their domestic goal of national liberation (Carsignol 2011: 53-62).

\section{The fragmentation of an emergent South Asian diaspora}

9 Once India, Pakistan, then Sri Lanka and later on Bangladesh obtained their independence, the worldwide solidarity and mutual interests which brought activists and nationalists from the diaspora and the subcontinent together partly dissolved. Pan SouthAsian regionalism gave way to territorial nationalism, and identities, both in the subcontinent and in the diaspora, were redefined along national, sometimes rival lines, as illustrated by blogger Razib Khan on the online discussion forum Sepia Mutiny: 'My maternal grandfather was born in British India and was Indian for most of his life (he was born in 1896). After 1947 he was Pakistani, and after 1971 he was Bangladeshi'. ${ }^{8}$ While overseas populations were busy negotiating their place in their country of adoption, the newly-defined countries in the subcontinent dissociated themselves from their migrants and engaged in a process of nation- and state-building centred on the territory.

The segmentation of migrants of South Asian origin in North America is also due to immigration and integration policies implemented by the host societies. The US Immigration and Nationality Act of 1965, and Canada Immigration Act of 1952, followed by the introduction of a Point-system (1967), progressively removed the ban on coloured migration and attracted a massive wave of South Asian migrants to North America. The news: 'Canada khulgaya!'9 (Canada opened up!) spread like wildfire from Ottawa to South Asia, and attracted migrants not only from India, but from the entire subcontinent as well as from the Caribbean, the Pacific and the Indian Ocean islands, and Eastern and Southern Africa. Due to their demographic growth and their increasing ethno-cultural and socioeconomic diversity, newcomers gathered into subgroups defined according to their region of origin, religious affiliation and/or social class. Furthermore, they were particularly encouraged to claim a nationality of origin in order to get symbolic recognition and material resources from multicultural programs. While most successful professionals integrated relatively easily into the mainstream society, where they epitomized the 'model minority' theory, ${ }^{10}$ the labourers and sponsored family members suffered racism, discrimination and exploitation.

\section{The construction of categories by academics and bureaucrats}

11 Primo-migrants originating from the subcontinent actually never used the 'South Asian' label, which was first coined by American politicians and academics more than half a century after their arrival. It was at the University of Pennsylvania that South Asian studies were inaugurated, with the creation of the first department of South Asia Regional Studies in 1948, funded by the Carnegie, Rockefeller, and Ford Foundations. ${ }^{11}$ The US State Department conceived this new area of research in order to support national interests in the Cold War (Dirks 2003: 2).

In the 1970s, while people originating from the subcontinent were classified as 'white' by the US Census Bureau (Table 1), the Association of Indians in America (AIA) successfully petitioned for inclusion in state and federal 'Asian' racial categories in order to assert political demands in a multicultural context, when resources were distributed on the basis of racial or religious criteria (Espiritu 1992). Minority status then provided the only 
mechanism for redress against the racial discrimination faced by Asian Indians, which their existing classification as 'white' obscured (Fisher 1980: 129). Since the 1980 Census, the 'Asian' category has offered a series of subcategories of which 'Asian Indian' is the only South Asian option, and it provides a fill-in blank for responses such as 'Pakistani' or 'Bangladeshi'. Despite this mutually agreed-upon official classification scheme, people of South Asian origin tend to differentiate themselves, and to be excluded from the definition of 'Asian Americans', which refers to East Asians in North American popular perception (Kibria 1996, 1998, Shankar \& Srikanth 1998).

Table 1 Census Classification in the USA

\begin{tabular}{|l|l|}
\hline Census Year & Census Classification, USA \\
\hline $\mathbf{1 9 1 0}$ & Other/Non-white Asiatic/Hindu \\
\hline $\mathbf{1 9 2 0}$ & Other/Hindu \\
\hline $\mathbf{1 9 3 0}$ & Hindu \\
\hline $\mathbf{1 9 4 0}$ & Hindu \\
\hline $\mathbf{1 9 5 0}$ & Other/Non-white/Asiatic Indian \\
\hline $\mathbf{1 9 6 0}$ & Other/Non-white/Hindu \\
\hline $\mathbf{1 9 7 0}$ & Other/White \\
\hline $\mathbf{1 9 8 0}$ & Asian Indian \\
\hline $\mathbf{1 9 9 0}$ & Asian or Pacific Islander/Asian Indian \\
\hline $\mathbf{2 0 0 0}$ & Asian Indian \\
\hline
\end{tabular}

Koshy, n.d.

13 The rubric 'South Asian' introduced in the Census by Statistics Canada refers to Canadians from India, Pakistan, Nepal, Bangladesh and Sri Lanka, as well as from Africa, the Caribbean, the Far East, the Indian Ocean and Fiji. This category is widely used both by academics and in politics, along with other common designations such as Indo-Canadians or East Indians-to avoid confusion with the Aboriginals, or 'Indians'.

In the subcontinent, the authorities of the home countries also have their own terminology to refer to their overseas populations. Within the last three decades, India, Pakistan and Nepal adopted official statuses to refer to their non-residents, such as People of Indian Origin, Non Resident Indian, Overseas Citizen of India, Overseas Pakistani or Non Resident Nepali. These administrative monikers have not been unanimously accepted by the migrants themselves: if some endorse them in order to take advantage of the resources to which they give access, others, on the contrary, reject the hegemonic definition, the elitist bias and the financial dimension these terms imply (Mallapragada 2006), or use them only in specific contexts to refer to their citizenship or their nationality. 


\section{The appropriation and transformation of the South Asian label by the migrants}

Beyond their normative function, the categories used by the state of origin or settlement also have a performative effect on migrants' self-perception. Within the so-called 'South Asian' population in North America, opinions about this exo-designation vary greatly, ranging from strong opposition to indifference to re-appropriation and transformation. For a segment of them, the moniker 'South Asian' overlooks internal differences and highlights common cultural denominators such as 'curry, cricket and Hindi cinema...' (Lal 2003). In the words of Hasan Altaf, a Pakistani poet and writer who grew up in America before relocating in Lahore:

I grew up on the East Coast, but if I looked for it, South Asia was right there. When I was in middle school, the Indians and Pakistanis and Bangladeshis gravitated towards each other, drawn by the opportunity to make fun of other people and complain about our parents to peers who would understand. [...] Later, when I was in college in New York, Indians and Pakistanis and Bangladeshis went to the same restaurants for a taste of home; we wound up at the same grocery stores, the same parties, the same movies; now, on Facebook, we laugh at the same memes. One could of course have looked for Pakistan, instead of South Asia, but the former was harder to find, and the differences so minimal. In the US and Canada and the UK, in the Middle East and in Singapore and in Hong Kong-surrounded that is by 'others', by people whose languages and backgrounds and cultures and experiences and expectations are more starkly different-Indians and Pakistanis begin to seem and to feel more alike-to feel, as it were, more 'South Asian'. (Altaf 2012)

The 'South Asian' branding is also used by identity entrepreneurs and community leaders as a strategy to reinforce internal cohesion among migrants originating from the subcontinent, and to maximize the group's demographic weight, particularly in multicultural societies where number matters. According to Zubair Choudhry, President of the South Asian Regional Cooperation Council of Canada, 'Our identity in Canada should be South Asian, not Indian, Pakistani, etc. We'll be stronger. Most of our culture is the same. If we are divided, we are not strong..$^{12}$ Indeed, it is acknowledged that:

[...] identifying as South Asian rather than Indian adds number and hence power within the US. Besides, regional differences among those of different South Asian countries are often less relevant than the commonalities based on our experiences and histories of immigration, treatment and location in the US. (Mohanty 2003: 127)

Yet, other migrants started to claim an alternative South Asian identity, in reaction to the 'Asian' census category, considered too vague and too closely associated with East Asians in the popular perception:

That the bulk of US South Asians do not see themselves as Asian is of little consequence in the wake of representations of immigrants from the Indian subcontinent as 'Asian' in the media, in the political domain, and in the academy. Indeed, the fait accompli of being named 'Asian', and the shared struggles this has produced (in terms of the similar experiences forged by being similarly reconfigured as a community), has led many South Asian progressives to create a political identity around the term 'South Asian'. The term 'South Asian' provides some measure of inclusion within the US, even if it is almost meaningless within South Asia itself. The cultural commonalities between Indians, Pakistanis, Sri Lankans, Nepalis, and Bangladeshis draw these migrants together, and the moniker 'South Asian' allows them to feel solidarity despite their different national origins and religious commitments. (Prashad 1999: 186-7) 
A new, ideologically-defined South Asian identity shaped by both transnational and local factors made its appearance during the 1980s-90s. First, the growing power of the conservative, religious and nationalist ideology known as Hindutva triggered a countermovement, both in India and in the diaspora. The destruction of the Babri mosque in Ayodhya (1992), the nuclear tests by both India and Pakistan (1998), the anti-Muslim pogrom in Gujarat (2002) and more generally, the rise of communalism in South Asia were denounced by 'actors of reconciliation in the diaspora' and 'progressive activists' throughout the world (Mohammad-Arif 2007). Leftist militants in North America adopted the 'South Asian' label to dissociate themselves from right-wing partisans of Hindu nationalism. As a set of socio-political ideas and ideals, 'South Asianism' thus started to compete with the conservative idea of Indianness, defined by Madhavi Mallapragada as 'traditionally uppercaste, middle class male Hindu (oftentimes North Indian Hindu) version of cultural tradition and practices' (Mallapragada 2000). A growing number of associations were created to promote pluralism and secularism in the diaspora and in the subcontinent. ${ }^{13}$ Summer camps for radical activists, such as Youth Solidarity Summer (YSS) or DC Desi Summer, were set up in a response to Hindutva camps. The importance of progressive ideology in South Asian mobilization is clearly articulated by the South Asian Progressive Action Collective:

\begin{abstract}
SAPAC was created as a space for South Asians with progressive values to share ideas and develop joint work. Our work promotes harmony among South Asian communities, social and economic justice, tolerance of difference, gender equity, and political mobilization to reach these goals. [...] If you are politically conservative or apolitical, you are welcome to join. Just please recognize that we are a group that was formed around a certain set of values and that will be engaged in work that reflects those values. If you are uncomfortable with Indians and Pakistanis working side by side, with a group that tries to make space for LGBTQ activists, or with poets and performers who explicitly address taboo issues, then you may not be comfortable at all our events. ${ }^{14}$
\end{abstract}

During the same decade in North America, the demographic growth and the new sociological diversity of South Asian migrants made them an easy target for extremist and nativist groups such as Canadian Knights of the Ku Klux Klan, Western Guard Party or 'dot busters', in a context marked by economic recession and the upsurge of xenophobia. In response to racial, socio-economic and political segregation, activists and social workers set up committees of self-defence, farmers' and workers' unions, anti-racist organizations and professionals' associations such as the East Indian Defense Committee, the British Columbia Organization to Fight Racism, the Canadian Farmworkers Union (CFU), the Indian People's Association in North America (IPANA), the Indian Professionals Organization of Canada, the East Indian Professional Residents of Canada (EIPROC) and the New York Taxi Workers Alliance (NYTWA).

Among the new wave of migrants, women were particularly vulnerable as they were exposed to both patriarchy inside their community, and racism outside. Gender-based associations created by and for women of South Asian origin, such as Manavi, Manushi, Maitri, Narika, Sakhi for South Asian Women, South Asian Women's Organization (SAWNET) or South Asian Women Centre (SAWC), started to provide educational and social services, and to fight domestic violence. These associations played a major role in the production of a progressive South Asian identity, all the more because women are traditionally at the core of the transmission of values from one generation to the other. 
21 Likewise, Lesbians, Gays, Bi-sexuals, Transsexuals and Queers (LGBTQ) suffered a double marginalization: within their own ethnic group, where intolerance for non-conventional sexual orientation dominated, but also in the mainstream society, where racism added to these prejudices. Movements emerged to defend LGBTQ's rights, such as Trikone, created in San Francisco in 1986, followed by South Asian Lesbian Gay Association of New York City, the Queer East and Khush DC, to speak for 'a minority within a minority community' and to build a bridge between 'Queer-ness' and 'Desi-ness'. South Asian feminism and LGBTQ activism, though firmly rooted in North America, also constituted a response to the recurrent brutality and discrimination against women and queers in the subcontinent.

The category 'South Asian' was subsequently adopted by intellectuals, academics, journalists and documentarians originating from the subcontinent, in particular cultural theorists such as Homi Bhabha, Ranajit Guha or Gayatri Chakravorty Spivak, who gave this label historical legitimacy, sociological validation and cultural substance. With the rise of Subaltern Studies, South Asian branding became a militant statement against elitism-both bourgeois and nationalist-in the writing on South Asian history and society (Guha \& Spivak 1988). This category has been used more recently by scholars in order to contest the myth of the model minority (Prashad 2000).

For Toronto-based activist and labour-organizer Maya Bhullar, Board chair of the Council of Agencies Serving South Asians (CASSA), South Asian-ness is inseparable from progressive militantism, as it embraces unity within diversity, culturally, ethnically and ideologically:

I have always been betwixt and between identities. [...] In terms of the diasporic identity, I guess I would call myself 'South Asian'. A lot of my work is about uniting progressive voices from different ethno-linguistic groups that make up the South Asian communities, and the term 'South Asian' is a good unifier. Even culturally, I identify as South Asian because the cultural group I identify with is largely Anglophone, and involved in the more progressive side of politics. [...] I started identifying as South Asian again in Washington DC, when a bunch of academics and progressives who were generally interested in South Asia formed the DC Collective for South Asia. [...] To me this is what the term 'South Asian' allows, a political identity, a progressive internationalism, a love of poetry, culture and art that is from all the different communities and cultures that are South Asian [...]. There is an underlying progressive. This is not to say that there isn't a progressive element in each component community. ${ }^{15}$

Cultural commonalities were then constructed a posteriori, in order to legitimize the birth of a community, despite its heterogeneity. In a hostile climate, ethnic identity produced a militant, secular, anti-nationalist ideology, which today paradoxically opposes the pioneers' nationalist ideals, while embracing their struggle for social justice. Gradually, the South Asian category has become a site of identity-building and collective contestation, used to oppose in particular the religious and conservative image of Indianness promoted by the "curry brigade"16 (Mallapragada 2000) on the one hand, and to contest the ongoing stereotypes and misconceptions in the host society on the other hand. It also offers an alternative to non-Indian national identities and politics. 


\section{Location, action and profile of South Asian activists}

Individual and collective mobilization in the name of a cultural 'South Asian-ness' or an ideological 'South Asianism' intensified during the last two decades, and became more and more visible, both offline and online. How can this recent type of mobilization be defined? How is it organized? Who are the activists at work? Where are they based? What are their objectives and their means of action? This section analyzes the structure of this mobilization, as well as the location, the field of action and the socio-economic profile of the people who define themselves as South Asians.

\section{Geographic implantation, field of action and means of mobilization}

Given that 'the distinction of real and imagined, or virtual, is not a useful one' (Wilson \& Peterson 2002), the following study of the South Asian movement is based on a combination of content analysis of websites and interviews with activists self-identified as South Asians. In order to analyze the structure of the South Asian 'virtual community' (Rheingold 1993), I used computer programs, Navicrawler and Gephi, ${ }^{17}$ to systematically explore 150 websites created by and for South Asians. This corpus was established by first selecting a few websites dedicated to 'South Asians' in the diaspora, ${ }^{18}$ then following the hypertext links ${ }^{19}$ which connected these websites to others, thus creating a digital network. In a second phase, the contents of these websites were scrupulously examined and classified according to their type of activity, means of mobilization, language, country of residence, field of mobilization and place of action. The mapping of the corpus highlights what brings different associations and individuals together, and sheds light on the goals and the means of action, as well as the ideas and ideals that constitute the foundations of the South Asian digital network (Carsignol 2012). These results were crossanalyzed with offline interviews of migrants and activists of South Asian origins.

The topology of the South Asian digital network (Figure 1) shows a very small number of hypertext links between the different websites of the corpus, and the absence of an agglomerated community around a single 'authority site'. Unlike Hindutva partisans, structured around key institutions in India and abroad (Therwath 2012), South Asian activists form a relatively loose network, defined by a very informal sense of belonging, a similar experience linked to migration and marginalization, a common ancestry in the subcontinent, and a set of implicitly shared values. 


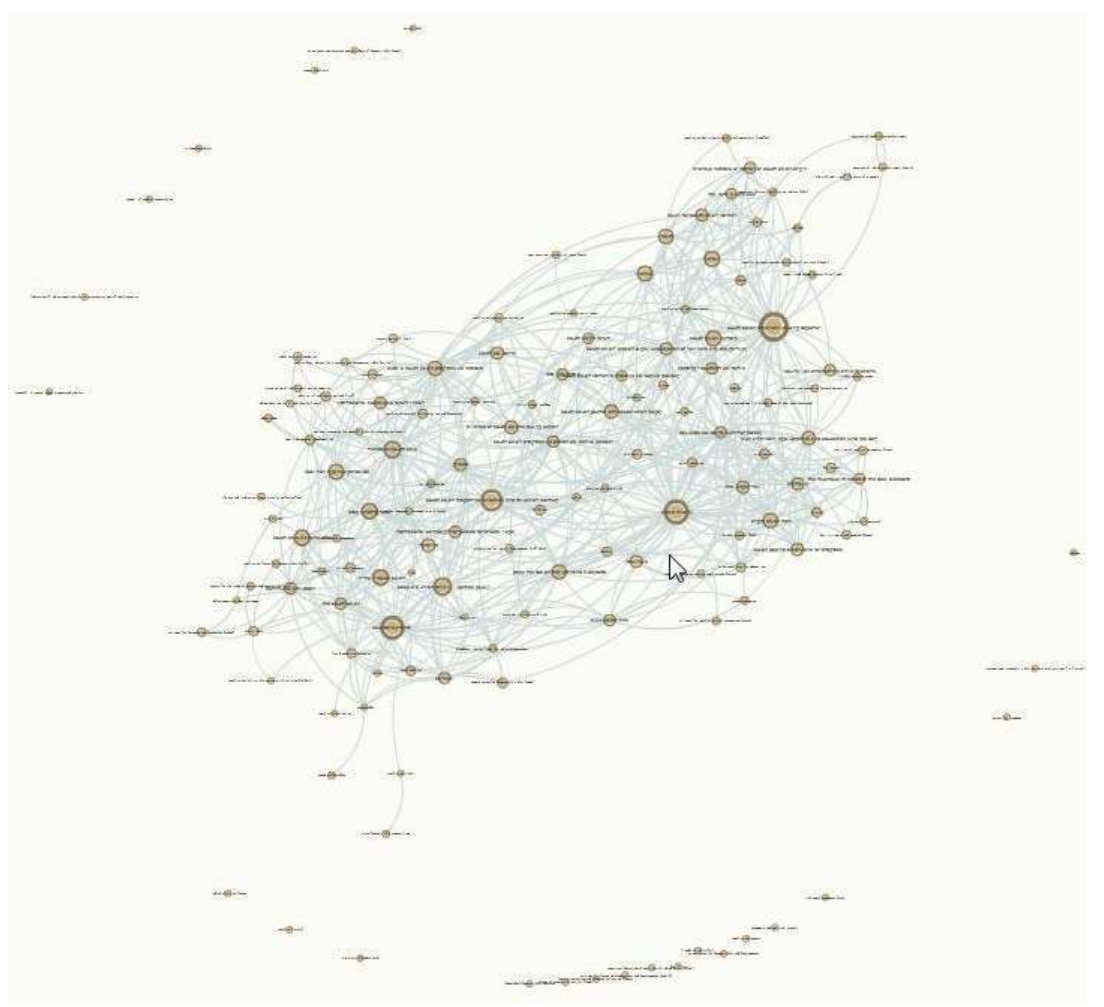

CARSIgNOL 2012

South Asian online forums, websites and digital platforms such as 'South Asia Citizen Web: Connecting dissenting voices from South Asia and its Diaspora since 1996', are explicitly devoted to reinforcing vertical contacts between migrants and their homeland, and creating new horizontal links between migrants themselves. Yet, the majority (80\%) of the 150 selected South Asian websites are not based in the subcontinent, but exclusively located in the diaspora, in particular in North America. Only $20 \%$ of the websites of the corpus are based in South Asia, and 5\% in Europe, while $16 \%$ of them do not mention their place of origin, and some are simultaneously implanted in different localities. More importantly, the majority of the websites (63\%) are devoted to the diaspora, while $43 \%$ are centred on the host country. Only a minority (19\%) are actually dedicated to social reforms in South Asia.

In terms of activities, the mapping of the corpus reveals four virtual clusters of websites (Figure 2). The first cluster (in red), devoted to local empowerment, is composed of associations based in North America, focused on the local or national level, and dedicated to the defence of workers (NYTA), sexual minorities (GAPIMNY, SALGA), women (Sakhi, Maitri, Manavi, Maika, Sneha), professionals (Sabha, NSAP, SAJA), and the promotion of pluralism (SAAPRI, The pluralism project at Harvard University). The second cluster (in green), dedicated to identity representation, is composed of cultural and artistic blogs and personal websites, based in North America and mainly identity-oriented, such as Sepia Mutiny, Pass the roti on the left hand side beta, Angry Asian Man, PremaLal, The Langar Hall, Down on the Brown side, and Turban Campaign. They provide information and platforms of debate, for both outreach (fight against racism and prejudice) and inreach (consolidation of the cohesion of the community). A third cluster (in blue) is 
animated by progressive magazines such as South Asian Citizens Web, South Asia Watch, Counter Currents, South Asian Magazine for Action and Reflection (SAMAR), Himal South Asian, and associations such as International Campaign for Justice for Bhopal, People's Union for Civil Liberties, Sanhati, South Asian Leftists dialoguing with Religion or South Asian Rights. These websites are principally devoted to the defence of Human rights and the promotion of pluralism and democracy in the subcontinent.

Figure 2: Clusters of mobilization of the South Asian radical e-diaspora, Zoom in

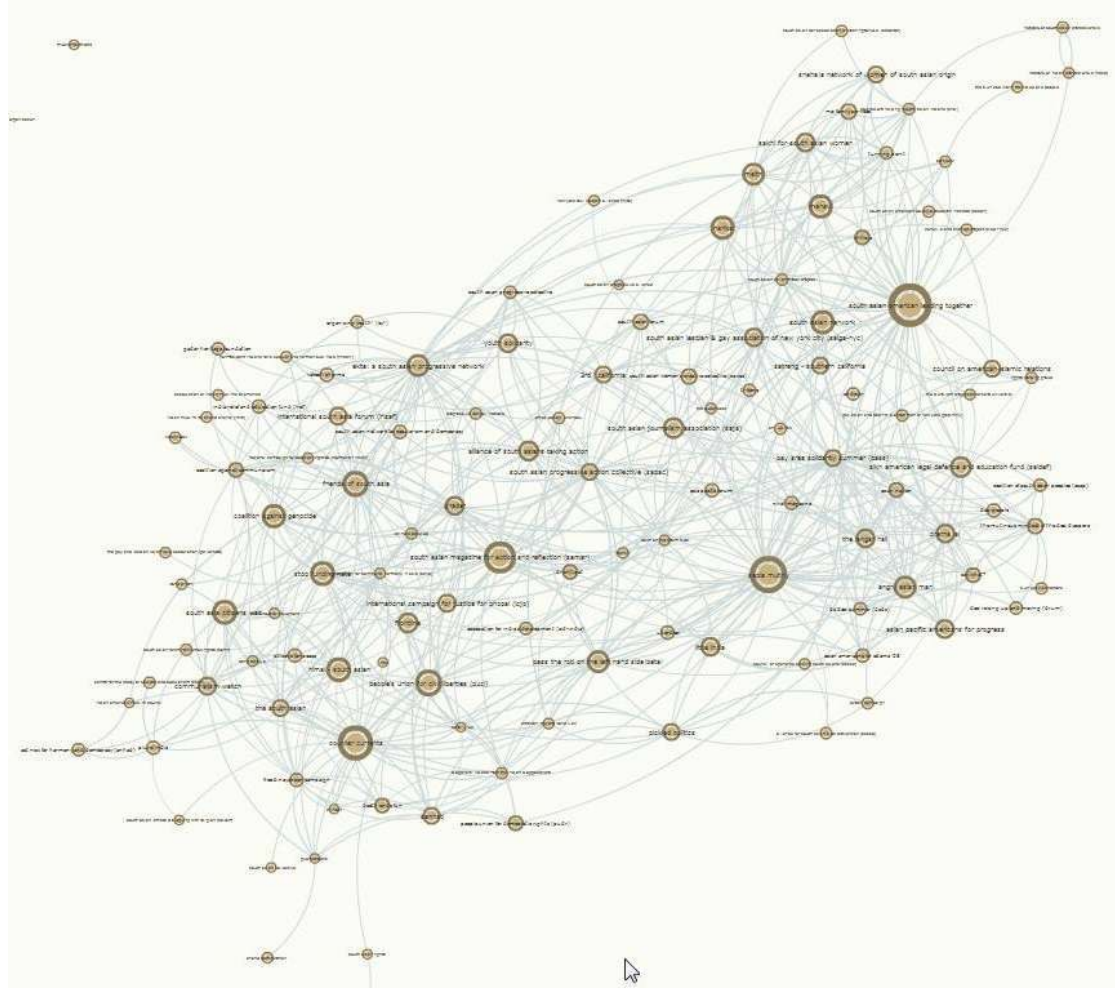

CARSIgNOL 2012

The last cluster (in yellow) is mobilized in favour of pluralism and secularism in North America. Most of its websites, such as Coalition against Genocide, Stop funding Hate and Ekta, emerged in the aftermath of the Gujarat massacre or the Ayodhya affair, in response to Hindutva's politics of hatred. The reference to South Asia seems to serve diasporic identity politics, a strategy that can be considered 'long distance activism', a variation of Benedict Anderson's 'long distance nationalism' (1988: 73-74). structure within the South Asian militant network. It also makes visible the fact that activists who define themselves as South Asians are mostly based in North America. South Asianism, as a socio-political and ethno-cultural counter-movement, could be qualified as 'post-diasporic' in the sense that it is not oriented toward the home country, but focused on the needs of migrants, or under-privileged members of minorities in general in their host society. The ideals of social or political change in the subcontinent seem to be mostly the symbolic alibi of mobilization aimed at promoting the various causes of South Asian migrants in North America.

In order to provide information, education and community services, South Asian activists combine both traditional means of action, such as demonstrations, petitions, fund- 
raising, boycotts, public meetings or lobbying, and electronic activism methods, such as online petitions, chain mailing-lists, e-forums or digital campaigns. In so doing, South Asian-ness has gained extensive outreach, as well as new substance. Interestingly, aesthetic creativity, both online and offline, plays a major role in defining what being South Asian in North America means: cultural politics and artistic activism are used not only as ways to produce subjectivity, but also as means of protest. Teesri Duniya Theatre (Third World Theatre), funded in Montreal in 1981, and Desh Pardesh ('at home abroad'), a-disciplinary culture and arts festival organized in Toronto from 1988 to 2001, epitomized a new generation of counter-culture in North America, combining identity affirmation and political involvement (Fernandez 2006). As mentioned in the Festival Program:

A non-profit community-based organization of artists, cultural producers and activists of South Asian origin committed to facilitating new expressions and encouraging the development of diasporic South Asian arts, culture and politics in the West. Desh Pardesh focuses on the perspectives, issues, artistic and cultural expressions of women, working class people, people with disabilities, lesbians, bisexuals and gay men, seniors and other progressive independent artists, hinkers and activists thinkers. It strives to forge links and work with other communities with compatible progressive objectives. (Desh Pardesh Festival 1995: 34)

Since the demise of Desh Pardesh, other initiatives, such as Diasporadics or Artwallah, continue to defend the participation of South Asian and other marginalized groups in North American cultural life, through artistic expression. Online associations such as the South Asian Visual Arts Centre (SAVAC) or the South Asian Progressive Action Collective (SAPAC) also provide platforms for artists to critically explore issues shaping South Asian identities and experiences, both in the diasporic context and in the subcontinent. Establishing a link between 'imagining' and 'imaging', Ananda Mitra shows how a virtual community ${ }^{21}$ 'can textually produce itself, thus imagine itself-as well as present itself to the outside world, and thus produce an image' (Mitra 1997:54). Indeed, blogs and individual websites such as 'pardonmyhindi', 'masalachai' or 'threadsandjewels' both reflect and reinforce a sense of pride and belonging, through the publication of personal essays, as well as photos, audio and video material. Likewise, collective sites such as Mutinous Mindstate or Sepia Mutiny connect politics, arts and identity, as a blogger pointed out when she described '[...] a site that gave me space to explore my identity with words, gave me the training grounds to build a community virtually, and allowed me the opportunity to influence political and advocacy issues affecting the South Asian community?'. ${ }^{22}$ Offline and online movements thus jointly participate in the production of South Asian subjectivities in the empowerment of migrants in North America, through an original combination of aesthetics and politics. Beyond South-Asian-ness, which refers to migrants' cultural and ethnic pride, South Asianism, as an ideology, promotes the ideals of social justice and pluralism, in reaction to the homogenizing ideology of the State, the essentializing effects of multiculturalism, and the dangers of communalism, aggressive nationalism or religious radicalism (Varghese 2006, Khandelwal 1997, Prashad 1999-2000, Mathew 1999-2000, Vaid 1999-2000). These objectives are strongly connected to the migrants' quest for integration and recognition in North America.

\section{Who are the South Asian activists?}


with precision their sociological profile, based on their age, caste, class or gender composition. Nevertheless, migrants who self-identify as South Asians are best defined in opposition to Hindutva militants, not only ideologically, but also sociologically. While the latter are typically scientists, most of whom are actually employed in the computer and information technology sector (Lal 1999b: 154, Spivak 1989: 277, Rai 1995: 43), the former, also highly educated, are mostly trained in humanities and engaged in academic, artistic or associative professions, such as professor and activist late Hari Sharma, film directors Ali Kazimi and Shonali Bose, and playwrights Rahul Varma and Sadhu Binning. Most of them reconcile intellectual reflections and social work, such as scholars Radhika Gajjala, Biju Mathew and Rinku Sen, who are also involved within the community. Others marry academic life with artistic production, such as Vivek Bald, filmmaker, writer and scholar, who was one of the pioneer DJs of Asian Underground music (under the pseudonym DJ Seraiki), and co-founded Mutiny, a New York South Asian club night, along with DJ Rekha. The latter not only spearheaded a mix of Bhangra and electronic music in the United States, but also actively supports the South Asian community through her work with SAKHI for South Asian Women, and Breakthrough, an organization active in the US and India, that promotes human rights through pop culture. As for Naeem Mohaiemen, author, artist $\left(\right.$ Shobak $^{23}$ ) and activist, one of the founders of Visible Collective, ${ }^{24}$ he engages art to question issues of identity and politics. These activists, artists and intellectuals not only share common ancestral roots and political ideals; they are also closely connected and work together, thus constituting an informal, but nonetheless real network in North America.

Another difference between Hindutva and South Asian activists is their gender ratio. Militants of the Hindu right, almost exclusively male, share a conservative ideology on the role of women in domestic and public spheres. South Asians activists, on the contrary, promote the equal participation of women and members of minorities in all strata of the society, and the members of their organizations are more or less equally distributed in terms of gender, when they are not entirely made up of women. Furthermore, while firstgeneration migrants tend to define themselves along national lines, later generations, born in North America, refer more readily to South Asian-ness (Shankar \& Srikanth 1998: 2).

Deeply secular, South Asian activists promote inter-faith harmony, tolerance and diversity, both in the diaspora and in South Asia. At Toronto Pride 2011, a contingent of Ismaili queers took part in the parade for the first time, holding banners such as 'Advocates for Pluralism', 'My faith will not crumble to your intolerance' or 'Allah is my ally', thus reconciling religion with progressive ideas and alternative lifestyles. Although many activists who define themselves as progressive South Asians claim to be atheist and vehemently denounce bigotry and religious fundamentalism, they share a common respect for religion and spirituality.

As for caste identity, which continues to define the social structure in South Asia and, to a lesser extent, to shape migrants' interactions in the diaspora, it is particularly salient among supporters of the Hindutva, who mostly claim an upper caste status and refuse to question the distribution of power between castes. South Asians activists, the majority of whom are from upper castes and privileged backgrounds, have consistently denounced the caste system in the name of secularism, human rights and social justice. They nevertheless mobilize separately, as indicated by the conspicuous absence of anti-caste movements in the activities of South Asian associations in North America. 


\section{The limits of 'South Asian-ness' and 'South Asianism'}

Though more and more widely accepted by migrants in North America, the 'South Asian' label remains highly problematic, 'masking deeply salient divisions of nationality, culture, religion and language' (Kibria 1996: 77). This section analyses the intrinsic limits of South Asian-ness as a contested category and an ill-defined identity, and South Asianism as a vague socio-political project.

\section{'South Asian? Qu'est-ce que c'est?'}

The question of the relevance of South Asian-ness is the object of intense debate within the diaspora, in North America in particular. It has been discussed, analyzed, deconstructed and criticized by identity entrepreneurs and culture producers themselves, at conferences, seminars and conventions such as the biannual National South Asian Summit, organized by South Asian Americans Leading Together (SAALT) and the South Asian Law Student Association (SALSA), organized for the fourth time in Washington DC, in April 2013. South Asian identity is also debated worldwide, as illustrated by the Symposium 'No Man's Land-Exploring South Asianness', chaired by the Institute of Contemporary Art in London in 2004, or the South Asian Diaspora Convention, set up in 2013 in Singapore. Last but not least, South Asian-ness is the subject of passionate discussions online, in forums and blogs.

In intellectual circles, the South Asian category is severely criticized by some prominent personalities as an opportunistic label deployed to obtain resources or influence representation politics. Academics, writers and artists condemn this descriptor for its monolithic and homogenizing connotations, its ghettoization and racialization effects (journalist Yasmin Alibhai Brown, researcher Jeevan Deol, Professor Sanjay Sharma, No Man's Land, 2004), its simplistic dimension or its exoticized nature (author-diplomat Pavan K Varma, No Man's Land, 2004). According to writer M. G. Vassanji (1996: 116), this category, 'imported from academia, is purely geographic, artificial, recent and entirely devoid of any imaginative force', especially because South Asians 'think of themselves and live as various communities'. In the words of Professor Arun Mukherjee: "South Asian' is a bureaucratic [...] umbrella term (used) to produce a unitary community that is not actually there' (1998: 29). As for Sunil Khilnani, Professor and Director of the King's College London India Institute, he deplores the 'unpoetic' nature of South Asia, who, unlike Europe, is deprived of any mythology (No Man's Land 2004). South Asian activists themselves, such as Biju Mathew (1996), point out the 'limits to South Asian-ness, unless re-articulated from within a strongly defined politics of class' (Ghosh 2007: 190). Similarly, Alaudin Ullah, the American playwright and performer of Bangladeshi origin, rejects this categorization:

I could easily say I'm American but due to racism I've never felt welcomed. And to those assimilated desis who felt 'American', they got their nigger wake up call after 9/11. [...] I don't label myself as Southasian. I guess I'm Bangladeshi American. I just prefer to be Alaudin Ullah, that's who I am. [...] Folks of European descent don't say I'm European they will say I'm Italian, French etc. [...] Latinos, most I know, don't call themselves that. They identify from their indigenous country. I grew up with Puerto Ricans who call themselves Puerto Ricans, Dominicans, Mexicans, etc who NEVER call themselves Latino or Hispanic. My family is from Bangladesh. If I say I'm

South Asia Multidisciplinary Academic Journal, 10 | 2014 
Southasian most folks will think I'm Chinese or Japanese. [...] So no I'm not a fan of the South Asian term. I've heard some apologists for this compromise state that by labeling oneself South Asian it shows we have solidarity with our brethren from the entire region (Bangladesh, Pakistan, India etc.) this is more academic babble. We don't have to surrender our identity to show our solidarity. By identifying ourselves from our indigenous ancestors, it instills an ability to show an alliance with our allies that we won't stand for bullshit especially when it comes to imperialism and culture bandits. We won't be a community unless we define ourselves instead of having academics bending over in order to get their next job at a fancy college to define us. Academics have force fed this term down our throats. My parents' generation never used this term and laborers who arrived here pre'65 immigration act don't have any solidarity with the academics who came here post '65 immigration act. The class differences are extreme so to use the term South Asian doesn't really paint an accurate picture of who we are. Lots of affluent Indians who live in suburbs of New York don't associate with the cab drivers, Dunkin donuts, Subway sandwich workers. ${ }^{25}$

41 When I told her about my ongoing research, a relative whom I was visiting, originating from Delhi and settled in Montreal for more than 20 years, asked me simply (in French): 'South Asian? Qu'est-ce que c'est?'26, thus indicating the meaningless of a term deprived of any grass-roots.

\section{Desi, Brown and other alternative labels}

In search of more appropriate appellations, overseas South Asians adopted in the 1980s the idiomatic term 'desi', derived from the Sanskrit देश (deśha: region, province, country), which refers to people, traditions and goods originating' from the homeland' in northern South Asian languages (Hindi, Hindustani, Urdu, Nepali...). Imagined by the migrants themselves, this term is now widely used by associations, magazines or blogs named after it, such as Desis Rising up and Moving (DRUM), The Mutinous Mindstate of the Desi Diaspora, Über Desi, and Desinews, as well as TV channels (Desi-TV) or radio stations (DeSi-RaDiO). Some use alternatively 'South Asian' and 'desi' to define themselves and their peers:

I love the word 'desi.' It is so beautiful. I can go around saying it over and over again. I'm of the view that it is the best word to describe ourselves ... it is an ironic word, because it means of the homeland, but it does not say what that homeland is. We who use it do not hearken back to the 'homeland' of the subcontinent, because we are generally not nationalistic in that sense. Our homeland is an imaginary one that stretches from Jackson Heights to the Ghadar Party, from the rallies against Dotbusters to the Komagata Maru, from the 1965 Immigration Act to Devon Street. This is a homeland that we can relate to and it is what makes us feel like we belong in something of a collectivity. Hence desi. And [the term] is under construction (Caswell, n.d.).

According to Susan Koshy, a desi identity offers:

[...] an alternative location for imagining communities that undoes the arbitrary borders drawn by colonialism and nationalism in the subcontinent; it offers a way of linking the fragments of the diaspora to each other and to the homeland; and it provides a framework for imagining cultural connection apart from the constraints of state power. Desi avoids naming the space of belonging in religious or national terms and thus, it offers a means of countering the fraught divisions that characterize South Asian politics and identities in the homelands. The word also overrides the distinction between those who live in the homeland and those who live elsewhere. This flexibility is a reflection of the period in which the term 
emerged, a period of growing economic, political and cultural connections between

South Asian nations and their overseas populations. (Koshy 2008: 36)

Yet, 'desi-ness' is not completely consensual either, as it refers essentially to people originating from the North of the subcontinent. Furthermore, the term 'desi' does not seem to capture the diversity, the cultural hybridity and the leftist ideology that is implicit in the South Asian label:

I think in a way South Asian emerges from the fact that all of us-Afghanis, Pakistanis, Bangladeshis, Indians, Sri Lankans, Mauritians-, the diaspora keep being lumped in with India when people see us. Funnily enough the broad term allows us to differentiate our identity. [...] Desi grounds us in the contested terrain of India-it is not pan-South Asian. It doesn't necessary refer to the same kind of militantism-it just gives us a home, which is problematic in way because the 'home' is much more India. It is more ethno-cultural and geographically focused. However, if we don't fight for the Desi label, it could easily be associated with Hindutava-so using Desi is more subversive because of the ethno-cultural link. Too many people think of Desi as the traditional. ${ }^{27}$

Along with 'South Asian' and 'Desi', the term 'masala' aims at transcending both ethnic and geographic criteria, in order to focus on the artistic and cultural creativity inspired by the subcontinent.

As for the ambivalent label 'Brown', it re-appeared recently in North America in a new, positive context. The multiplication of online associations, websites and blogs such as republicofbrown.com, brownpundits.com or brownout.blogspot.fr, whose motto is 'One in a million Brooklyn browns', reflects the growing importance of 'Browness' in South Asian self-perception and identity politics. This term refers to pan-ethnic attributes close to racial profile, thus confirming Kibria's intuition that a larger South Asian population will make 'greater efforts to gain a political voice' and that as part of this process, it will increasingly turn to 'racial self-definition and positioning' (Kibria 1998: 73). Interestingly, if this label is increasingly popular among people of South Asian descent, especially from the second generation, it is considered derogative, if not racist when used by "nonBrowns'. This phenomenon echoes back to the 'Black is Beautiful' movement of the 1960s, which turned skin colour and ethnic attributes into a source of pride and a means of social protest. According to Karen Aguilar-San Juan, the label 'Brown' is not so much a self-designation, but results from North American racial categorizations, which were internalized by members of 'coloured' minorities:

Many young Asian Americans 'have been driven to affiliate as people 'of color' or 'Third World' people because they have been excluded from the mainstream, but not because they have developed a critique of racism-or of the poverty and violence racism often implies. As a result, many of these young people define their political activism solely in terms of asserting their identity, and are driven to accept essentialist notions of race and ethnicity. (Aguilar-San Juan 1993: 9)

Yet, the idea of 'Browness' can also be perceived as the promotion of ethnic and cultural hybridity,-a way to escape the traditional white or black dichotomy in North America, an alternative to cultural homogeneity and racial purity. Nevertheless, the 'Brown' identity claimed by some South Asians does not include other non-South Asian populations, even though some of them take pride in calling themselves 'Brown' in reaction to the terms 'Latinos' or 'Hispanics' for instance. 


\section{A limited impact in the subcontinent}

48 Whereas South Asian diasporic mobilization is fairly influential in North America, it is difficult to measure its impact in the subcontinent. In theory, communication technology should stimulate the emergence of new forms of political engagement from a distance, as well as new forms of local self-representations, connected to the homeland and to the host society, thus making the South Asian mobilization and identity production in North America part of a transnational movement. In practice, the transnational dimension of North American South Asianism is more symbolic than real.

Indeed, the leftist South Asian mobilization in North America is not so much focused on South Asia, but aims at improving the migrants' place in their host society. In the 1970s, a few diasporic organizations, such as the Indian People's Association in North America, were dedicated to social and political change in the subcontinent, but as IPANA's founder member Mahil Harinder stated:

IPANA was directed in India, but we realized that Indians in Canada needed to improve their life in Canada, so we organized BCOFR. In the late 1970s, thousands of Indians were living here, but had no laws to protect them. We established 'Canadian Farmworkers Union'. We lobbied the government. ${ }^{28}$

An exception to the local anchorage of South Asianism in North America is the SAARC of Canada, whose President, Zubair Choudhry, promotes inter-community harmony and a regional unity in the subcontinent, but more for economic, liberal reasons:

In Canada, we are Canadians of South Asian origin. We are 'one', South Asians. No divisions. Why being divided? We, in our organization, have representatives of the 7 countries (India, Pakistan, Bangladesh, Sri Lanka, Nepal, Bhutan and Maldives). We think that South Asia should become one region without border, with one single currency and free trade. [...] This organization is proposing to the government of Canada that Canada should join SAARC as an observer, and establish a SAARC fund, to put resources to find out what we can do. [...] We try to promote peace and harmony within South Asian community in Canada. [...] We want the government of Canada to officially apply for membership in SAARC, and help in trade, culture, tourism, build strategic relations. ${ }^{29}$

The movement in favour of a South Asian unity and cooperation, which emerged in the subcontinent in 1985 with the creation of the SAARC, does not have any connection with the diasporic production of identity and quest for integration in North America. The panregional organization, whose principal goal is to "promote the welfare of the peoples of South Asia, to improve their quality of life, to accelerate economic growth, social progress and cultural development and to provide all individuals the opportunity to live in dignity and to realize their full potential' (SAARC Charter, 1985), failed to fulfil its objectives and to develop as a forum for discussion and conflict resolution. Its biggest challenge is the power asymmetry in the region (Kher 2012). Given the postcolonial hegemonic position of India in the subcontinent, small countries such as Nepal or Sri Lanka favourably rally the geostrategic idea of South Asia in order to benefit from their association with the major players in the subcontinent, while Pakistan and Bangladesh, on the contrary, refuse to be merged into a region centred on New Delhi. As for India, regionalism constitutes a challenge to its predominance in the area (Lal 2003). In fact, the idea of South Asia itself is questioned by its own supporters, who consider it a 'set of inclusive and overlapping local and regional identities', a 'confederation of lifestyles and life-support systems' (Ashis Nandy 2001). 

civil society organizations, labour unions, peasant organizations, women's groups, ecologists and human rights activists from the entire subcontinent gathered in 1995 to create the People's SAARC, a grass-roots lobbying group based in Kathmandu whose mission is to forge a 'people's union of South Asia'. Local associations dedicated to the defence of underprivileged minorities, the promotion of peace, education, democracy, human rights and inter-communal harmony, and the protection of the environment, have multiplied throughout the subcontinent, and some of them are connected to the network of diasporic leftist South Asians, such as the South Asia Forum for Human Rights (SAFHR), Sangat South Asia and Act Now for Harmony and Democracy (ANHAD). Nevertheless, most of the initiatives taken in the subcontinent in the name of panregionalism are centred on South Asia itself.

South Asianism thus seems ambivalent, embodying different ideologies and identities, whether formulated in the subcontinent-where it promotes cooperation and social change at the regional level, in the name of cultural commonalities and economic and political mutual interests-or in the diaspora in general. In North America in particular, South Asianism constitutes a space of dissent, where alternative identities and narratives are produced by some activists of South Asian descent, in a double quest for integration and differentiation.

\section{Conclusion}

In this digital age, information and communication technology weakens the ties between culture and locality, and generates new forms of mobilization, able to transcend borders and defy hegemonic narratives. Are these social movements yet more transnational? Unlike the primo-migrants' pan-South Asian solidarity, which aimed at changing the political map in the subcontinent, today's South Asianism is mostly focused on the migrants' local preoccupations in their host societies. The ideal of inter-communal harmony between South Asians, formulated by leftist migrants of South Asian descent, seems to be more a strategy for local empowerment than an objective to reach in the subcontinent. Nevertheless, this wishful dream, formulated in the diaspora, and sometimes accompanied by transnational initiatives, does certainly have an impactlimited but real-in the subcontinent. Acting as a transmission belt from one country to another, overseas South Asian mobilization undoubtedly resonates in the subcontinent, where it not only raises political and cultural consciousness, but also transforms social practices through transnational associations, family connections and the media.

This article highlights the role of the diaspora in North America as a singular site of construction and contestation of identity and ideology, between partisans of a Hindu nationalism on the one hand, secularist nationalists on the other hand, and regionalists, supporters of a cultural, political and economic pan-South Asian unity. Indeed, overseas leftist activists, or 'South Asianists', have produced an original, post-national, postdiasporic, ideological movement, based not only on common ancestral origins, but also shared values such as pluralism, secularism and the protection of marginalized minorities, in response to both local and transnational factors. The evolution of the South Asian concept, and the transformations of the identity to which it refers, illustrate the equivocal and ambivalent relationship between identity and category. Indeed, the categorization process has a dual, performative influence on the production of identity.

South Asia Multidisciplinary Academic Journal, 10 | 2014 
'South Asian', this once meaningless, if not depreciative label, turned out to become the very means of resistance to traditional, homogeneous and pre-defined identities, both within the community of migrants and in the society at large. More than an abstract concept, a mere intellectual construction, South Asianism is, for many people, part of their reality, it constitutes their cultural background and the framework of their social life. As Toronto-based activist Maya Bhullar sums it up: 'I found my community in the people the term 'South Asian' attracts'.

\section{BIBLIOGRAPHY}

Anderson, Benedict (1988) The Spectre of Comparisons. Nationalism, Southeast Asia, and the World, London \& New York: Verso.

Aguilar-San Juan, Karen (1993) 'Linking the Issues: From Identity to Activism', in Karen AguilarSan Juan (ed.), The State of Asian America: Activism and Resistance in the 1990s, Boston: South End, pp. 1-15.

Altaf, Hasan (2012) 'Brown as the Mouths of Rivers', A Country of Our Own-A Symposium on ReImagining South Asia, Seminar, 632, URL: http://www.india-

seminar.com/2012/632/632_hasan_altaf.htm.

Appadurai, Arjun (1990) 'Disjuncture and Difference in the Global Cultural Economy', Public Culture, 2(2), pp. 1-24.

Bald, Vivek (2013) Bengali Harlem and the Lost Histories of South Asian America, Harvard: Harvard University Press.

Binning, Sadhu; Hundal, Sukhwant (n.d.) 'Darshan Singh Canadian: Ten years in Canada', Watan Punjabi, URL: http://watanpunjabi.ca/pdf/darshan-singh-canadian-english.pdf.

Butler, Judith (1997) The Psychic Life of Power: Theories in Subjection, Stanford: Stanford University Press.

Carsignol, Anouck (2012) “South Asianism': Militantisme politique et identitaire en ligne’, in Dana Diminescu (ed.), E-Diasporas Atlas: Exploration and Cartography of Diasporas on Digital Networks, Paris: Editions de la FMSH, http://www.e-diasporas.fr/working-papers/CarsignolSouthAsianLeftistMobilisation-FR.pdf.

Carsignol, Anouck (2011) L'Inde et sa diaspora: influences et intérêts croisés, à l'île Maurice et au Canada, Paris, Genève: Presses Universitaires de France.

Carter, Marina; Ng Foong Kwong, James (1995) Forging the Rainbow: Labour Immigrants in British Mauritius, Mauritius: Alfran Co Ltd.

Caswell, Michelle (n.d.) An interview of Vijay Prashad, 'Smashing the Model Minority Myth', Asia Society, URL: http://asiasociety.org/policy/social-issues/human-rights/smashing-myth-modelminority?page $=0,2$.

Das Gupta, Monisha; Gupta, Charu; Teaiwa, Katerina Martina (2007), 'Rethinking South Asian Diaspora Studies', Cultural Dynamics, 19(2/3), pp. 125-140. 
Das Gupta, Monisha (2006) Unruly Immigrants: Rights, Activism and Transnational South Asian Politics in the United States, Durham \& London: Duke University Press.

Deleuze, Gilles; Guattari, Félix (2004), Anti-〔Edipus, London \& New York, Continuum, [1972].

Diminescu, Dana (2011) Guide d'analyse et de rédaction, Projet e-Diasporas Atlas, WorkingPaper.

Dirks, Nicholas B. (2003) 'South Asian Studies: Futures Past', in David L. Szanton (ed.), The Politics of Knowledge: Area Studies and the Disciplines, Berkeley: University of California Press/University of California International and Area Studies Digital Collection, vol. 3, pp. 1-56.

Dumm, Christopher; Jain, Nisha (2004) 'A Portrait of the Indian American Community: An InDepth Report based on the US Census', The Indian American Centre for Political Awareness (IACPA), August.

Espiritu, Yen Le (1992) Asian American Pan-ethnicity: Bridging Institutions and Identities, Philadelphia: Temple University Press.

Fernandez, Sharon (2006) 'More than Just an Arts Festival: Communities, Resistance, and the Story of Desh Pardesh', Canadian Journal of Communication, 31(1), URL: http://www.cjc-online.ca/ index.php/journal/article/viewArticle/1778/1902.

Fisher, Maxine P. (1980) The Indians of New York City: A Study of Immigrants from India, New Delhi: Heritage Publishers.

Gajjala, Radhika (2002) 'An Interrupted Postcolonial/Feminist Cyberethnography: Complicity and Resistance in the 'Cyberfield' ', Feminist Media Studies, 2(2), pp. 177-93.

Gajjala, Radhika (2003) 'South Asian Digital Diasporas and Cyberfeminist Webs: Negotiating Globalization, Nation, Gender and Information Technology Design', Contemporary South Asia, 12(1), pp. 41-56.

Gajjala, Radhika; Mamidipudi, Annapurna (1999) 'Cyberfeminism, Technology and International 'Development”, Gender and Development, 17(2), pp. 8-16.

Ghosh, Papiya (2007), Partition and the South Asian Diaspora: Extending the subcontinent, Delhi: Routledge.

Guha, Ramachandra (2002) 'The United States of South Asia', Himal Magazine, URL: www.himalmag.com/2002/january/round_table.htm.

Guha, Ranajit; Spivak, Gayatri Chakravorty (eds.) (1988) Selected Subaltern Studies, New York: Oxford University Press.

Juergensmeyer, Mark (1997) 'The ‘Ghadar Syndrome': Nationalism in an Immigrant Community', Punjab Journal of Politics, 1(1), pp.1-22.

Juergensmeyer, Mark; Barrier, Gerald N. (1979) Sikh Studies: A Comparative Perspectives on a Changing Tradition, Berkeley: Graduate Theological Union, pp. 173-90.

Khandelwal, Madhulika (2002) Becoming American, Being Indian: An Immigrant Community in New York City, Ithaca \& NY: Cornell University Press.

Kher, Priyanka (2012) 'Political Economy of Regional Integration in South Asia, UNCTAD, URL: http://unctad.org/en/PublicationsLibrary/ecidc2013misc1_bp5.pdf.

Kibria, Nazli (1996) 'Not Asian, Black or White? Reflections on South Asian American Racial Identity', Amerasia Journal, 22(2), pp. 77-86.

Kibria, Nazli (1997) ‘Community Organizing in an Asian Group: Asian Indians in New York City', Another Side, 5(1), pp. 23-32. 
Koshy, Susan (1998) 'Category Crisis: South Asian Americans and Questions of Race and Ethnicity', Diaspora: A Journal of Transnational Studies, 7(3), pp. 285-320.

Koshy, Susan (n.d.) 'Historicizing Racial Identity and Minority Status for South Asian Americans', Asian Pacific American Collective History project, URL: http://www.sscnet.ucla.edu/history/faculty/ henryyu/APACHP/teacher/research/koshy.htm.

Koshy, Susan; Radhakrishnan, R. (2008) Transnational South Asians: The Making of a Neo-Diaspora, Delhi: Oxford University Press.

Kurien, Prema (2003) 'To Be or Not to Be South Asian: Contemporary Indian American Politics', Journal of Asian American Studies, 6(3), pp. 261-88.

Landzelius, Kyra (2006) Native on the Net: Indigenous and Diasporic Peoples in the Virtual Age, London: Routledge.

Landow, George P. (1992) Hypertext, Baltimore: John Hopkins University Press.

Lal, C.K. (2003) 'The Necessary Manufacture of South Asia', Himal South Asian, Thematic Issue: Asia Special, URL: http://www.himalmag.com/2003/january/asia_special_2.htm.

Lal, Vinay (1999) 'The Politics of History on the Internet: Cyber-diasporic Hinduism and the North American Hindu Diaspora', Diaspora: A Journal of Transnational Studies, 8(2), pp. 137-72. Leonard, Karen (1997) The South Asian Americans, Wesport: Greenwood Press.

Lessinger, Johanna (1999) 'Class, Race, and Success: Indian Americans confront the American Dream', in Carla Petievich, The Expanding Landscape: South Asians and the Diaspora, New Delhi: Manohar, pp. 15-39.

Mallapragada, Madhavi (2000) 'Indian Women in the US Diaspora and the 'Curry Brigade': The Politics of Nation, Gender and sexuality on the Web', presented at Constructing Cyberculture(s): Performance, Pedagogy, and Politics in Online Spaces, 6-7 April, University of Maryland, USA.

Mallapragada, Madhavi (2006) 'Home, Homeland, Homepage: Belonging and the Indian-American Web', New Media \& Society, April, 8(2), pp. 207-27.

Mathew, Biju (1996) 'Deploying History/Subverting Nationalism: Notes on South Asian Politics in the Metropolis', abstracts for the $25^{\text {th }}$ Anniversary Conference on South Asia, Center for South Asia, University of Wisconsin-Madison, 17-20 October.

Mathew, Biju (1999) ‘Dubious Generations: A Discussion with Vivek Bald', Amerasia Journal, 25(3), pp. 195-205.

Mathew, Biju; Esser, Dominique; Fitzpatrick, Kevin; Kazem, Mohammed; Raja, Rizwan (1999), "Reorganizing Organizing: Immigrant Labor in North America', Interview with New York Taxi Workers' Alliance', Amerasia Journal, 25(3), pp. 171-81.

Mitra, Ananda (1997) 'Virtual Commonality: Looking for India on the Internet', in Steve Jones (ed.), Virtual Culture: Identity and Communication in Cybersociety, New York, Sage, pp. 55-79.

Mohammad-Arif Aminah (2007) 'The Paradox of Religion: The (re)Construction of Hindu and Muslim Identities amongst South Asian Diasporas in the United States', South Asia Multidisciplinary Academic Journal, 1, URL: http://samaj.revues.org/index55.html.

Mohanty, Chandra Talpade (2003) Feminism without Borders: Decolonizing Theory, Practicing Solidarity , New Delhi: Zubaan.

Morning, Ann (2001) 'The Racial Self-Identification of South Asians in the United States', Journal of Ethnic and Migration Studies, 27(1), pp. 61-79. 
Mukherjee, Arun (1998) Postcolonialism: My Living, Toronto: TSAR.

Nandy, Ashis (2002) 'Indic Hindustan', Himal Magazine, January.

'No Man's Land-Exploring South Asianness' (2004) Symposium, Institute of Contemporary Art, London, 22 May, http://www.akademi.co.uk/media/downloads/NML_report.pdf.

Petray, Theresa Lynn (2011) 'Protest 2.0: Online Interactions and Aboriginal Activists', Media Culture Society, 33, pp. 923-40.

Petersen, William (1966) ‘Success Story Japanese-American Style’, New York Times Magazine, January $6^{\text {th }}$.

Prashad, Vijay (2004) ‘Dusra Hindustan’, Seminar, URL: http://www.indiaseminar.com/2004/538/538\%20vijay\%20prashad.htm.

Prashad, Vijay (2006) ‘Ethnic Studies Inside Out', Journal of Asian American Studies, 9(2), June, pp. 157-76.

Prashad, Vijay (1999) 'From Multiculture to Polyculture in South Asian American Studies', Diaspora: A Journal of Transnational Studies, 8(2), pp. 185-204.

Prashad, Vijay (2010) 'History of the Desi Umbilical', Himal, December , URL:http:// himalmag.com/component/content/article/3460-history-of-the-desi-umbilical.html.

Prashad, Vijay (2000) The Karma of Brown Folk, Minneapolis: University of Minnesota Press.

Prashad, Vijay; Mathew, Biju (1999/2000) 'Satyagraha in America: The Political Culture of South Asians in the US', Amerasia Journal, 25(3), pp. ix-xiv.

Puri, Hari K. (1983) Ghadar Movement: Ideology, Organization, and Strategy, Amritsar: Guru Nanak Dev University Press.

Puri, Hari K. (1975) The Ghadar Party: a Study in Militant Nationalism, PhD Dissertation in Political Science, Guru Nanak Dev University: Amritsar.

Rai, Amit S. (1995) 'India On-Line: Electronic Bulletin Boards and the Construction of a Diasporic Hindu Identity', Diaspora: A Journal of Transnational Studies, 4(1), pp. 31-57.

Rheingold, Howard (1993) The Virtual Community: Homesteading on the Electronic Frontier, Reading, Addison-Wesley.

Sabbagh, Daniel (2003) 'Le statut des ‘Asiatiques' aux Etats Unis : l'identité américaine dans un miroir', Critique Internationale, 20, July $20^{\text {th }}$.

Sahoo, Ajaya Kumar; De Kruijf, Johannes G. (eds) (2014) Indian Transnationalism Online: New Perspectives on Diaspora, Surrey: Ashgate.

Shah, Ghanshyam (2002) 'Caste, Hindutva and Hideousness', Economic and Political Weekly, 37(15), April 13-19, pp. 1391-3.

Shankar, Lavina Dhingra; Srikanth, Rajini (eds.) (1998) A Part, Yet Apart: South Asians in Asian America, Philadelphia: Temple University Press.

Shankar, S. (1999) 'Cultural Politics amongst South Asians in North America', Amerasia Journal, 25 (3), pp. 151-61.

Singh, Amardeep (2007) “Names Can Wait': The Misnaming of the South Asian Diaspora in Theory and Practice', South Asian Review, 28(1), pp. 13-28.

Spivak, Gayatri Chakravorty (1989) ‘Who Claims Alterity?', Remaking History, Barbara Kruger and Phil Mariani (eds.), Seattle: Bay, pp. 269-92. 
Stone, Allucquere Rosanne (1991), Will the Real Body Please Stand Up?: Boundary Stories about Virtual Cultures, Cambridge (MA): MIT Press.

Therwath, Ingrid (2012) 'Cyber-Hindutva: le nationalisme hindou, la diaspora et le web', in Dana Diminescu (ed.), E-Diasporas Atlas: Exploration and Cartography of Diasporas on Digital Networks, Paris: Editions de la FMSH, http://www.e-diasporas.fr/working-papers/Therwath-Hindutva-FR.pdf

Vaid, Jyotsna (1999/2000) ‘Beyond a Space of our Own: South Asian Women’s Groups in the US’, Amerasia Journal, 25(3), pp.111-26.

Varghese, Linta (2006) 'Constructing a Worker Identity: Class, Experience, and Organizing in Workers' Awaaz', Cultural Dynamics, 18, pp.189-211.

Vassanji, M. G. (1996) 'Life at the Margins: In the Thick of Multiplicity’, in Deepika Bahri (ed), Between the Lines, Philadelphia: Temple University Press, pp.111-20.

Wilson, Samuel; Peterson, Leighton (2002), 'The Anthropology of Online Communities', Annual Review of Anthropology, 31, pp. 449-67.

Zaidi, Akbar S. (2002) 'Are we All Indians Now?', The Little Magazine, 3(4), URL: http:// www.littlemag.com/bodypolitic/akbarzaidi.html.

\section{NOTES}

1. This paper is a substantially revised version of an article published in the E-Atlas diaspora, Paris, Editions de la FMSH, April 2012. It has been presented at the conference: 'The Idea of South Asia', Centre d'Etudes de l'Inde et l'Asie du Sud (CEIAS), EHESS-CNRS, Paris, 13 November 2012.

2. These eight countries are members of the South Asian Association for Regional Cooperation (SAARC), an organization created in 1985 to promote 'peace, stability, amity and progress in the region', see http://www.saarc-sec.org/SAARC-Charter/5/.

3. The neologism 'South Asianism' was coined by journalist Siddharth Varadarajan in 2001 at a Himal roundtable.

4. In this article, the term 'queer' is used to refer to all the different types of non-conventional sexuality-based identities, also mentioned under the acronym LGBT (Lesbian, Gay, Bisexual, Transsexual).

5. The term 'Satyagrahi' refers to members of the civil resistance movement, known as 'Satyagraha ' (Truth Force), initiated by Mohandas K. Gandhi in South Africa in 1906.

6. The term 'Girmitiyas' refers to Indian indentured workers brought to Fiji in the XIX ${ }^{\text {th }}$ century, after having signed an 'agreement' (hence its name).

7. Indentured workers were people transported from India to the French, British and Dutch plantation colonies between 1838 and the 1920s, in order to replace the slaves in the plantations. The 'indenture system' has been compared to 'a new system of slavery' (Tinker 1974). It is now the object of a more nuanced interpretation, which positions it halfway between forced slavery and chosen migration (Carter 1995).

8. Razib Khan, June 15, 2011, http://sepiamutiny.com/blog/2011/06/15/what_is_brownde/.

9. Late Hari Sharma, Professor of Sociology at Simon Fraser University, militant activist, interview by author, Burnaby (BC), October 2006.

10. The notion of 'model minority' was first coined by William Petersen (1966) to describe Americans of Asian origin as ethnic minorities who, despite their marginalization, reached a success level higher than the average in the US. Their success was measured in terms of average income, high educational achievement, high family stability and low criminality rate. According to critics (Prashad 2000 \& 2006, Leonard 1997, Lessinger 1999, Sabbagh 2003, Dumm \& Jain 2004), 
this stereotype sets up high expectations and understates the achievements of individuals within 'model minorities'. It ignores factors such as selective immigration, affirmative action and cultural influences which might privilege some groups over others. It also tends to generalize the socio-economic level of success of a few migrants to a whole population, thus embarrassing the non-successful members of a model minority by implying that they are responsible for falling short of the expected level of achievement and assimilation. Furthermore, this idea pits minority groups against each other by ethnicizing socio-economic success, and implying that the nonsuccessful communities are either at fault for not reaching the same level of achievement, or are 'culturally' not endowed to do so. Finally, this stereotype is used to justify the exclusion of model minorities in the distribution of assistance programs, based on the very cultural and ethnic (mis)conceptions which, less than a century ago, were used to vilify the same categories of people. At the same time, this myth is invoked to counter the demands of groups such as Blacks and Hispanics for equal rights and socio-economic change.

11. University of Pennsylvania Bulletin, South Asia Regional Studies, Announcement for the Academic Year 1949-50 and Summer Session, 1949.

12. Zubair Choudhury, interview by author, Mississauga (Ontario), November 2006.

13. Such as: Coalition against Genocide, Coalition against Communalism, Stop Funding Hate, Communalism Watch, South Asians against Police Brutality and Racism, International South Asian Forum (INSAF), South Asia Research and Resource Centre (CERAS), Forum of Indian Leftists (FOIL), Friends of South Asia (FOSA), Alliance for a Secular and Democratic South Asia, South Asia Left Democratic Alliance (SALDA), South Asians against Police Brutality and Racism (SAPBR), Campaign to Stop Funding Hate, the coalition Building Bridges etc...

14. http://www.sapac.org/about.htm.

15. Maya Bhullar, interview by author, Toronto, October 2013.

16. The 'curry brigade', a self-identifying term that circulates in the US based 'Silicon India', not only refers to the culinary habits of South Asian migrants, but also to their collective, army-like organization. This expression implicitly alludes to the right wing, nationalist, conservative and religious movement Hindutva, which promotes the 'hinduization of politics, and the militarisation of Hinduism'.

17. Navicrawler is a tool of exploration of the web, which analyses the contents and the structure of web pages and their hypertext links. Gephi is an interactive visualization and exploration platform for all kinds of networks and complex systems, dynamic and hierarchical graphs. See http://ediasporas.ticmigrations.fr/?lang=en.

18. The research was only conducted in English, on the assumption that this is the common language that most of the migrants originating from the subcontinent share, especially in a diasporic context, all the more so online. It was also assumed that, had there been websites published in South Asian languages, they would have a translated version in English, for obvious outreach and practical reasons. This English-only research, based on a specific term highly popular in North America, undoubtedly constitutes a geographical and socio-economic bias. By using this method, the research explicitly focuses on South Asian-ness in North America. Although a comparative approach with South Asian-ness in the United Kingdom would be particularly interesting, it goes beyond the scope of this article.

19. Hypertext links are defined as 'text composed of blocks of words (or images) linked electronically by multiple paths, chains, or trails in an open-ended, perpetually unfinished textuality described by the terms link, node, network, web and path...' (Landow 1992: 3).

20. This graph (Figure 1) helps visualize the South Asian e-diaspora's network, constituted of 'migrant sites', that is websites made or managed by, for or about migrants. The hypertext links (in grey) connect various websites to each other. Each website of the corpus is materialized by a knob. The orientations up/down and right/left of the graph do not have any correlation with North/South and East/West. Likewise, the distance between different knobs has no importance: 
only the position of the knobs and their inter-connectivity matter, with the exception of the insulated ones, which could have as well been represented by a list. When a set of sites form a relatively dense and homogeneous cloud, it is called a 'cluster'. If a number of sites are connected to each other in the shape of a spider web, they are considered a 'community'. A 'hub' is a knob with many outbound links. An 'authority' is a very influential knob, with many inbound links. The more inbound links a knob has, the bigger it appears on the graph (Diminescu 2011).

21. A virtual community can be defined as a space 'in which people still meet face-to-face, but under new definitions of both 'meet' and 'face' ... virtual communities [are] passage points for collections of common beliefs and practices that unite people who were physically separated' (Stone 1991: 85).

22. Taz 2012, URL: http://sepiamutiny.com/blog/2012/04/01/tazs-top-ten-and-thanks/ \#more-8827.

23. http://www.shobak.org/.

24. Visible Collective (2004-2007) was a coalition of artists, activists, and lawyers looking at hyphenated migrant identities.

25. Alaudin Ullah, interview by author, Toronto, October 2013.

26. Simrit Chatwal, interview by author, Montréal, October 2013.

27. Maya Bhullar, interview by author, Toronto, October 2013.

28. Mahil Harinder, Deputy Chief Minister, Former President of the Human Rights Commission, interview by author, Toronto, October 2006.

29. Zubair Choudhry, South Asian Regional Cooperation Council of Canada, interview by author, Mississauga, November 2006.

\section{ABSTRACTS}

Traditionally, states see the diaspora at best, as an instrument of long distance nationalism, and at worst, as a source of internal conflict. Yet, migrants who define themselves as South Asians in North America transcend subnational and national borders in the name of a pan-regional identity. Beyond cultural or ethnic commonalities anchored in the Indian subcontinent, 'South Asianism' is emerging as a form of political consciousness and radical activism, mobilized against racial discrimination and socio-economic injustice. This article, based on ethnographic fieldwork combined with an analysis of digital networks, explores the construction and the limits of the South Asian category, identity and ideology in North America. It sheds new light on the paradoxes of a transnational, post-diasporic mobilization, which claims roots in the subcontinent but is essentially anchored in the host society, where it is dedicated to migrants' cultural affirmation, civic participation and socio-economic empowerment.

\section{INDEX}

Keywords: cultural activism, South Asian diaspora, ideological mobilization, identity politics, ethnicity 


\section{AUTHOR}

\section{ANOUCK CARSIGNOL}

Research fellow, Centre d'Etudes et de Recherche sur l'Inde et l'Asie du Sud (CERIAS), UQAM, Montréal 